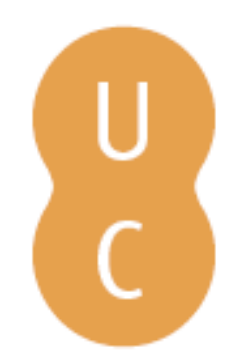

\title{
pommalina
}

\section{Darwin, evolution, evolutionisms: a selective chronology (1809-2009)}

Autor(es): $\quad$ Pita, João Rui; Pereira, Ana Leonor; Fonseca, Pedro Ricardo

Publicado por: Imprensa da Universidade de Coimbra

URL

persistente: URI:http://hdl.handle.net/10316.2/31277

DOI: $\quad$ DOI:http://dx.doi.org/10.14195/978-989-26-0342-1_2

Accessed : $\quad$ 26-Apr-2023 13:49:07

A navegação consulta e descarregamento dos títulos inseridos nas Bibliotecas Digitais UC Digitalis, UC Pombalina e UC Impactum, pressupõem a aceitação plena e sem reservas dos Termos e Condições de Uso destas Bibliotecas Digitais, disponíveis em https://digitalis.uc.pt/pt-pt/termos.

Conforme exposto nos referidos Termos e Condições de Uso, o descarregamento de títulos de acesso restrito requer uma licença válida de autorização devendo o utilizador aceder ao(s) documento(s) a partir de um endereço de IP da instituição detentora da supramencionada licença.

Ao utilizador é apenas permitido o descarregamento para uso pessoal, pelo que o emprego do(s) título(s) descarregado(s) para outro fim, designadamente comercial, carece de autorização do respetivo autor ou editor da obra.

Na medida em que todas as obras da UC Digitalis se encontram protegidas pelo Código do Direito de Autor e Direitos Conexos e demais legislação aplicável, toda a cópia, parcial ou total, deste documento, nos casos em que é legalmente admitida, deverá conter ou fazer-se acompanhar por este aviso. 
Ana Leonar Pereira João Rui Pita

Pedro Ricarda Fonseca (eds.)
Darwin,

Evalution,

Evolutionisms

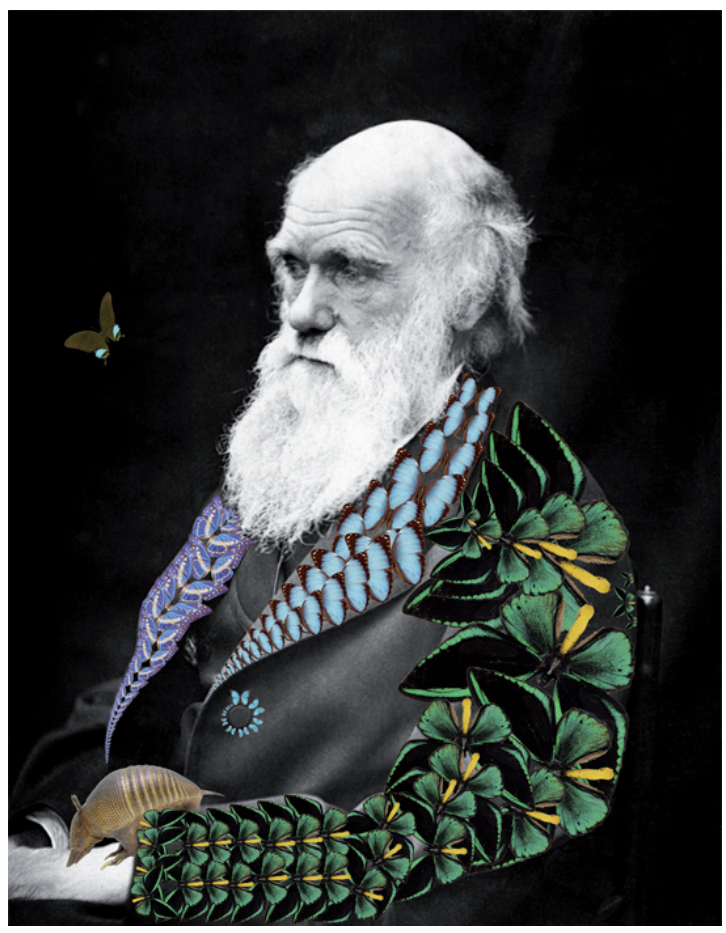


João Rui Pita

Faculdade de Farmácia; CEIS20-Grupo de História e Sociologia da Ciência, Universidade de Coimbra, Portugal Ana Leonor Pereira

Faculdade de Letras; CEIS20-Grupo de História e Sociologia da Ciência, Universidade de Coimbra, Portugal Pedro Ricardo Fonseca

FCT; Faculdade de Letras; CEIS20-Grupo de História e Sociologia da Ciência, Universidade de Coimbra, Portugal

\author{
Darwin, Evolution, Evolutionisms: \\ A Selective Chronology (1809-2009)
}

1809 Birth of Charles Robert Darwin (1809-1882)

1809 Philosophie zoologique by Jean Baptiste Monet, chevalier de Lamarck (1744-1829)

1817 Le règne animal distribué d'après son organisation, pour servir de base à l'histoire naturelle des animaux et d'introduction à l'anatomie comparée by Georges Cuvier (1769-1832)

1830 Debate between Georges Cuvier and Geoffroy Saint-Hilaire (1772-1844) at the Academie des Sciences

1830-1833 Principles of Geology by Charles Lyell (1797-1875)

1831-1836 Voyage of H. M. S. Beagle

1835 Charles Darwin visits the Galapagos Islands

$1838 \quad$ Charles Darwin conceived his theory of natural selection

1839 Journal of Researches into the Geology and Natural History of the Various Countries Visited by H.M.S. Beagle by Charles Darwin

1843 Richard Owen (1804-1892) establishes the distinction between homology and analogy

$1844 \quad$ Vestiges of the Natural History of Creation by Robert Chambers (1802-1871), published anonymously

1856 Discovery of Neanderthal remains in Germany

1858 Charles Darwin receives an unpublished essay from Alfred Russel Wallace (1823-1913) that proposes a theory of natural selection very similar to his

1858 Joint presentation of extracts of Charles Darwin's earlier writings on natural selection and Alfred Wallace's unpublished essay to the Linnean Society of London by Charles Lyell and Joseph Dalton Hooker (1817-1911)

1859 On the Origin of Species by Means of Natural Selection, or the Preservation of Favoured Races in the Struggle for Life by Charles Darwin

1860 The first translations of The Origin of Species are published

1860 Debate between Bishop Samuel Wilberforce (1805-1873) and Thomas Henry Huxley (1825-1895) at the British Association for the Advancement of Science

1861 Discovery of Archaeopteryx lithographica remains in Germany 
1862 William Thomson, Lord Kelvin (1824-1907), estimated that the age of the Earth was between 20 million and 400 million years

1863 Evidence as to Man's Place in Nature by Thomas Henry Huxley

1864-1867 Principles of Biology by Herbert Spencer (1820-1903)

1866 Gregor Mendel (1822-1884) publishes his work on the inheritance in pea plants

1868 The Variation of Animals and Plants Under Domestication by Charles

\section{Darwin}

$1868 \quad$ Natürliche Schöpfungsgeschichte by Ernst Hæckel (1834-1919)

1871

The Descent of Man, and Selection in Relation to Sex by Charles Darwin

1872

1872

The Expression of the Emotions in Man and Animals by Charles Darwin

1876

Sixth edition of The Origin of Species

1882

Darwiniana by Asa Gray (1810-1888)

1883

1885

Death of Charles Darwin

Francis Galton (1822-1911) coins the term "Eugenics"

August Weismann (1834-1914) presents the Continuity of the Germplasm Theory

1887 The life and letters of Charles Darwin, including an autobiographical chapter edited by Francis Darwin (1848-1925)

1889 Francis Galton presents the Law of Ancestral Heredity

1891 Discovery of Java Man by Marie Eugene Dubois (1858-1940)

1894

1896

1897

Materials for the Study of Variation by William Bateson (1861-1926)

James Mark Baldwin (1861-1934) presents the "Baldwin Effect"

William Thomson, Lord Kelvin, advances with a new estimate on the age of the Earth: between 20 and 40 million years

1900 Mendel's laws are independently "rediscovered" by Hugo de Vries (1848-1935), Carl Correns (1864-1933) and Erich von Tschermak (1871-1962)

1901-1903 Die Mutationslehre by Hugo de Vries

1902

1903

Mutual Aid: A Factor of Evolution by Peter Kropotkin (1842-1921)

Wilhelm Ludwig Johannsen (1857-1927) introduces the distinction between genotype and phenotype

1904 Nelson Ernest Rutherford (1871-1937), based on the new knowledge of radioactivity, discredits Lord Kelvin's reduced estimates on the age of the Earth

1908 Establishment of the Hardy-Weinberg law

1909 Centenary of Charles Darwin's birth and the $50^{\text {th }}$ anniversary of the first publication of The Origin of Species. Cambridge is the main stage of the celebrations, gathering scientists and dignitaries from many different countries

1909 Constantin Mereschkowsky (1855-1921) introduces the concept of Symbiogenesis

1909 Discovery of the Burgess Shale by Charles Walcott (1950-1927)

1911 Lucien Cuénot (1866-1951) introduces the concept of Pre-adaptation

1912 Alfred Wegener (1880-1930) presents the Theory of Continental Drift

1912 Discovery of the Piltdown Man 

(1866-1945), Alfred H. Sturtevant (1891-1970), Calvin B. Bridges (1889-1938) and Herman Joseph Muller (1890-1967) The Origin of Life (in Russian) by Alexander Ivanovich Oparin (1894-1980)

Discovery of the Taung Baby by Raymond Dart (1893-1988)

Scopes Monkey Trial in Dayton, Tennessee

The Origin of Life by John Burdon Sanderson Haldane (1892-1964)

Trofim Lysenko (1898-1976) rejects the validity of Mendelian Genetics and of chromosome theory (1890-1962)

"The roles of mutation, inbreeding, crossbreeding, and selection in evolution" by Sewall Wright (1889-1988)

\section{The Causes of Evolution by J. B. S. Haldane}

Genetics and the Origin of Species by Theodosius Dobzhansky (1900-1975)

\section{The Material Basis of Evolution by Richard B. Goldschmidt}

(1878-1958)

Variation and Evolution in Plants by George Ledyard Stebbins (1906-2000)

Discovery of the double helix by James Watson (b. 1928) and Francis Crick (1916-2004)

New estimates indicate that the Earth is 5 or 6 billion years old Henry Bernard D. Kettlewell's (1907-1979) studies on predation in peppered moths demonstrated the effects of natural selection in the wild Le phénomène humaine by Pierre Teilhard de Chardin (1881-1955)

Centenary of the The Origin of Species and the $150^{\text {th }}$ anniversary of Charles Darwin's birth. Chicago is the centre of the major celebrations, gathering scientists and dignitaries from around the world "The Genetical Evolution

\section{Molecular Evolution}

1972 "Punctuated Equilibria: An Alternative to Phyletic Gradualism" by Niles Eldredge (b. 1943) and Stephen Jay Gould (1941-2002) 


\section{Bibliography}

BOWLER, Peter J. - Evolution: the history of an idea, 25 th Anniversary Edition, With a New Preface. $3^{\text {rd }}$ edition, completely revised and expanded. Berkeley, Los Angeles and London: University of California Press, 2009.

FONSECA, P. R.; PEREIRA, A. L.; PITA, J. R. - "A história do evolucionismo no século XX: metodologias e perspectivas historiográficas”, Estudos do Século XX, Coimbra, No 11, 2011, pp. 373-388.

GAYON, Jean - Darwin et l'après Darwin: Une histoire de l'hypothèse de sélection naturelle. Paris: Editions Kimé, 1992.

GOULD, Stephen Jay - The stucture of evolutionary theory. Cambridge, Mass. and London: The Belknap Press of Harvard University Press, (sixth printing) 2002.

HODGE, J.; RADICK, G. (eds.) - The Cambridge Companion to Darwin. New York: Cambridge University Press, 2003.

MAYR, Ernst - The growth of biological thought: diversity, evolution and inheritance. Cambridge, Mass.: The Belknap Press of Harvard University Press, 1982.

PEREIRA, Ana Leonor - Darwin em Portugal. Filosofia. História. Engenharia Social-(1865-1914). Coimbra: Livraria Almedina, 2001.

PEREIRA, A. L.; FONSECA, P. R. - "The Darwin centennial celebrations in Portugal". In: GLICK, T.; SHAFFER, E. (eds.), The Reception of Charles Darwin in Europe, vol. 3, London and New York: Continuum, (In Press). - Series on the Reception of British and Irish Authors in Europe.

RUSE, Michael - The Evolution Wars: A Guide to the Debates. $2^{\text {nd }}$ ed. Millerton, NY: Grey House Publishing, $2^{\text {nd }}$ ed., 2009.

SEGERSTRÅLE, Ullica - Defenders of the truth: the battle for science in the sociobiology debate and beyond. Oxford and New York: Oxford University Press, 2000.

TORT, Patrick (dir.) - Dictionnaire du darwinisme et de l'évolution. Paris: Presses Universitaires de France, 3 vols., 1996.

WYHE, John (ed.) - The Complete Works of Charles Darwin Online, 2002-. http://darwin-online.org.uk/ 